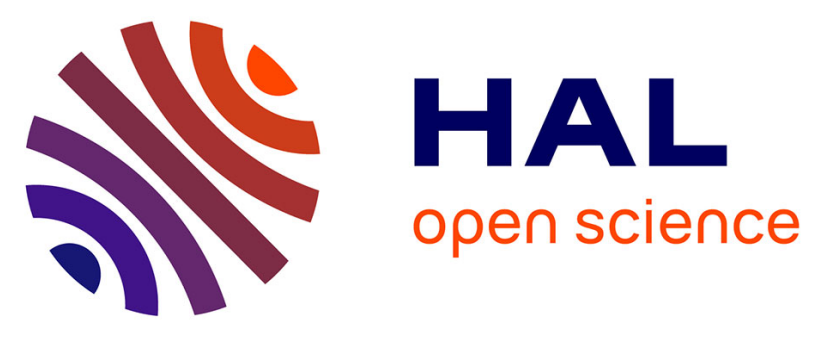

\title{
Influence of organic selenium supplementation on the accumulation of toxic and essential trace elements involved in the antioxidant system of chicken
}

Athanasios C Pappas, Evangelos Zoidis, Constantinos A Georgiou, Nikolaos Demiris, Peter F Surai, Konstantinos Fegeros

\section{To cite this version:}

Athanasios C Pappas, Evangelos Zoidis, Constantinos A Georgiou, Nikolaos Demiris, Peter F Surai, et al.. Influence of organic selenium supplementation on the accumulation of toxic and essential trace elements involved in the antioxidant system of chicken. Food Additives and Contaminants, 2011 , pp.1. 10.1080/19440049.2010.549152 . hal-00671232

\section{HAL Id: hal-00671232 \\ https://hal.science/hal-00671232}

Submitted on 17 Feb 2012

HAL is a multi-disciplinary open access archive for the deposit and dissemination of scientific research documents, whether they are published or not. The documents may come from teaching and research institutions in France or abroad, or from public or private research centers.
L'archive ouverte pluridisciplinaire $\mathbf{H A L}$, est destinée au dépôt et à la diffusion de documents scientifiques de niveau recherche, publiés ou non, émanant des établissements d'enseignement et de recherche français ou étrangers, des laboratoires publics ou privés. 


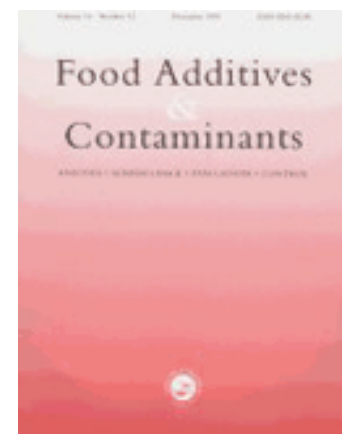

\section{Influence of organic selenium supplementation on the accumulation of toxic and essential trace elements involved in the antioxidant system of chicken}

\begin{tabular}{|c|c|}
\hline Journal: & Food Additives and Contaminants \\
\hline Manuscript ID: & TFAC-2010-309.R1 \\
\hline Manuscript Type: & Original Research Paper \\
\hline $\begin{array}{r}\text { Date Submitted by the } \\
\text { Author: }\end{array}$ & 08-Dec-2010 \\
\hline Complete List of Authors: & $\begin{array}{l}\text { Pappas, Athanasios; Agricultural University of Athens, Nutritional } \\
\text { Physiology and Feeding } \\
\text { Zoidis, Evangelos; Agricultural University of Athens, Nutritional } \\
\text { Physiology and Feeding } \\
\text { Georgiou, Constantinos; Agricultural University of Athens, } \\
\text { Chemistry Laboratory } \\
\text { Demiris, Nikolaos; Agricultural University of Athens, Animal } \\
\text { Breeding and Husbandry } \\
\text { Surai, Peter; University of Glasgow, Division of Environmental and } \\
\text { Evolutionary Biology } \\
\text { Fegeros, Konstantinos; Agricultural University of Athens, Nutritional } \\
\text { Physiology and Feeding }\end{array}$ \\
\hline Methods/Techniques: & ICP/MS, Metals analysis - ICP/MS, Toxicology - animal study \\
\hline Additives/Contaminants: & Heavy metals - cadmium, Metals - selenium \\
\hline Food Types: & Animal feed \\
\hline
\end{tabular}

\section{SCHOLARONE ${ }^{\text {w }}$ Manuscripts}




\title{
Influence of organic selenium supplementation on the accumulation of toxic and essential trace elements involved in the antioxidant system of chicken
}

\author{
Athanasios C. Pappas ${ }^{1 *}$, Evangelos Zoidis ${ }^{1}$, Constantinos A. Georgiou ${ }^{2}$, Nikolaos Demiris ${ }^{3}$, \\ Peter F. Surai ${ }^{4}$, Konstantinos Fegeros ${ }^{1}$ \\ ${ }^{1}$ Department of Nutritional Physiology and Feeding, Faculty of Animal Science and \\ Aquaculture, Agricultural University of Athens, 75 Iera Odos, 11855, Athens, Greece \\ ${ }^{2}$ Chemistry Laboratory, Agricultural University of Athens, 75 Iera Odos, 118 55, Athens, \\ Greece \\ ${ }^{3}$ Department of Animal Breeding and Husbandry, Faculty of Animal Science and \\ Aquaculture, Agricultural University of Athens, 75 Iera Odos, 11855, Athens, Greece \\ ${ }^{4}$ Division of Environmental and Evolutionary Biology, University of Glasgow, Glasgow, G12 \\ 8QQ, Scotland, UK
}

\begin{abstract}
*Correspondence: A.C. Pappas, Department of Nutritional Physiology and Feeding, Faculty of Animal Science and Aquaculture, Agricultural University of Athens, 75 Iera Odos, 11855, Athens, Greece. Tel: +30 210 5294415, Fax: +30 210 5294413, E-mail: apappas@aua.gr
\end{abstract}

Keywords: antioxidant system, cadmium, chicken, copper, iron, selenium, zinc 


\begin{abstract}
The aim of the study was to investigate the interactions between selenium (Se) and some trace elements, both toxic and essential, which are all involved in the antioxidant system. A total of 128 day-old chicks (Gallus gallus, broilers) were used to investigate the effect of Se yeast supplementation on the accumulation of cadmium $(\mathrm{Cd})$, copper $(\mathrm{Cu})$ iron $(\mathrm{Fe})$ and zinc $(\mathrm{Zn})$. There were 4 replicates of 4 dietary treatments: T1 (basal diet with no added Se, analyzed to contain $0.21 \mathrm{mg} \mathrm{kg}^{-1}$ ), T2 (T1 with $0.15 \mathrm{mg} \mathrm{kg}^{-1} \mathrm{Se}$ added), T3 (T1 with $0.3 \mathrm{mg} \mathrm{kg}^{-1} \mathrm{Se}$ ) and $\mathrm{T} 4$ ( $\mathrm{T} 1$ with $3.0 \mathrm{mg} \mathrm{kg}^{-1} \mathrm{Se}$ ). At $4^{\text {th }}$ and $6^{\text {th }}$ week, 2 chickens per replicate pen were sacrificed for whole blood, breast muscle and liver sample collections. Samples were analyzed by ICPMS. Supplementation with Se-yeast, not only increased Se concentration but also reduced Cd concentration in the tissues. Selenium was negatively correlated with $\mathrm{Cd}$ and positively correlated with $\mathrm{Zn}, \mathrm{Cu}$ and $\mathrm{Fe}$. Cadmium was negatively correlated with $\mathrm{Zn}$ and $\mathrm{Cu}$. Zinc was positively correlated with $\mathrm{Cu}$. Iron was negatively correlated with $\mathrm{Cu}$ and uncorrelated with $\mathrm{Zn}$ and $\mathrm{Cd}$. The balance between $\mathrm{Se}, \mathrm{Cu}, \mathrm{Fe}$ and $\mathrm{Zn}$ is important for proper antioxidant defence since they are integral part of various antioxidant enzymes.
\end{abstract}




\section{Introduction}

Trace elements are minerals that are needed in minute quantities for the proper growth, development, and physiology of the organism. In living animal organisms, trace elements are bound to various ligands in cellular membranes, cytoplasm and blood. They are transported and stored via several proteins including but not limited to albumin, ceruloplasmin, transferrin and metallothioneins which are often non-specific and so may be sites of interaction between trace elements (Serra-Majem et al. 2009; Southgate et al. 1989; Strachan 2010). They can be classified as essential including iron (Fe), manganese (Mn), copper $(\mathrm{Cu})$, zinc $(\mathrm{Zn})$ and selenium(Se), probably essential nickel $(\mathrm{Ni})$, vanadium $(\mathrm{V})$ and cobalt $(\mathrm{Co})$ both required in the diet, but that may have toxic effects at supraoptimal concentrations (Underwood and Suttle 1999) and potentially toxic including but not limited to aluminum $(\mathrm{Al})$ arsenic $(\mathrm{As})$, cadmium $(\mathrm{Cd})$, lead $(\mathrm{Pb})$, mercury $(\mathrm{Hg})$ not required in the diet, causing chronic negative effects at low concentrations and lethal effects at high concentrations (Bires et al. 1995; Uluozlu et al. 2009). The absorption, accumulation and toxicity of each metal may be affected by diverse factors, including interactions with other metals. Indeed, interactions between toxic and essential metals are central to mineral balance and the antioxidant defence system (López-Alonso et al. 2007; Pappas et al. 2010a; Pappas et al. 2010b).

Selenium is a trace element that plays a key role in the antioxidant defence system. It is the integral part of at least 25 selenoproteins and via their actions protects the organism from harmful actions of free radicals (Pappas et al. 2008). Copper and $\mathrm{Zn}$ are two of the most abundant trace elements found in the human body and are involved in the metabolism of oxygen and the biochemistry of redox reactions (Klotz et al. 2003). The enzyme CuZnsuperoxide dismutase (SOD) catalyzes the dismutation of superoxide, which is constantly formed during aerobic metabolism, to oxygen and hydrogen peroxide. Copper and $\mathrm{Zn}$ are joined in cellular defense against oxidants by Se to form a triad of trace elements that are involved in cytosolic antioxidant defense: hydroperoxides, including $\mathrm{H}_{2} \mathrm{O}_{2}$, are reduced to the respective alcohols or water in a reaction that is catalyzed by the selenoenzyme glutathione peroxidase (GPx) with glutathione (GSH) as the electron donor (Klotz et al. 2003). Similarly to $\mathrm{Cu}$ and $\mathrm{Zn}$, iron's ability to accept or donate electrons makes it central to the catalytic activity of many redox-active enzymes. Iron is an integral part of several classes of enzymes, including cytochromes, enzymes involved in the synthesis of steroid hormones, detoxification of foreign substances in the liver, synthesis of neurotransmitters and DNA synthesis and 
breakdown (Gambling et al. 2008). Cadmium disrupts the antioxidant enzyme system, resulting in increased oxygen radical production, which causes damage to membranous structures such as mitochondria and endoplasmic reticulum (Schrauzer 2009). Cadmium is known to induce the production of nitric oxide (NO) and reactive oxygen species (ROS) such as hydroxyl radicals $\left(\mathrm{OH}^{*}\right)$, superoxide anions radicals $\left(\mathrm{O}_{2}{ }^{-}\right)$and $\mathrm{H}_{2} \mathrm{O}_{2}$. Furthermore, $\mathrm{Cd}$ interferes with antioxidant enzymes, causes enzyme dysfunction and lipid peroxidation (Ognjanovic et al. 2010).

Essential trace metals may modify health risks from exposure to nonessential toxic metals. A well known example of this is the reduction of Cd toxicity after pre-treatment with Zn or the simultaneous administration of Zn with Cd (Jemai et al. 2007; Webb 1979). On the other hand, the ingestion of a diet that is deficient in a particular essential element can enhance the accumulation and toxicity of some toxic metals. Calcium, Fe and $\mathrm{Zn}$ deficiency, for instance, enhance susceptibility to $\mathrm{Cd}$ and $\mathrm{Pb}$ toxicity (Goyer 1997; Jihen et al. 2008; WHO 1996). Additionally, it has been demonstrated that toxic metals can disrupt trace element metabolism. Cadmium toxicity affects $\mathrm{Ca}$ metabolism either by direct toxicity to bone or indirectly from renal toxicity (Goyer 1997; Pappas et al. 2010a; Webb 1979). Interactions between metals can occur at levels of exposure well below those at which toxicity may be detected. In addition, domestic animals have the advantage that they are an important source of food for humans and good biomonitor species for metal contamination worldwide (Lopez Alonzo et al. 2004; Petersson-Grawe et al. 1997; Tuzen and Soylak 2007).

The present study was part of a project designed to assess the effect of the inclusion of Se in broiler's diet on the gene expression of antioxidant enzymes, trace element interactions and Se impact on fatty acid composition and oxidative stability of lipids in meat. Previously, we evaluated how Se affected gene expression of Se dependent and non-Se dependent antioxidant enzymes (Zoidis et al. 2010). The aim of the present study was to investigate the interactions between Se and some trace elements, both toxic and essential, which are all involved in the antioxidant system. Therefore, the concentration of $\mathrm{Se}, \mathrm{Cd}, \mathrm{Cu}, \mathrm{Fe}$ and $\mathrm{Zn}$ and their interactions were assessed in blood, liver and breast muscle tissues of 4- and 6 week old broilers fed diets supplemented with Se-yeast. 


\section{Materials and methods}

Animals, Diets and Design

Details of the genotype, nutrition and husbandry of the broilers used in this study have been described previously (Zoidis et al. 2010). In brief, a total of 128 day-old Cobb chickens (broilers) were used. The chickens were obtained from a commercial hatchery. All chickens had the same Se-status because the broiler breeder flock was fed a commercial diet with 0.20 $\mathrm{mg} \mathrm{kg}^{-1}$ Se. There were 4 replicate pens of 4 dietary treatments namely T1, T2, T3 and T4 randomly allocated in the house. Pen was the experimental unit. There were 8 chickens per pen, 32 per treatment. The study was designed considering that a concentration of $0.15 \mathrm{mg} \mathrm{Se}$ per kg of diet is recommended by the United States National Research Council (NRC 1994), that the maximum allowed Se inclusion level in the United States is $0.3 \mathrm{mg} \mathrm{kg}^{-1}$ (Payne et al. 2005) and that current total maximum EU authorized level of Se in complete feed is $0.5 \mathrm{mg}$ $\mathrm{kg}^{-1}$. In T1, chickens were fed a basal diet without Se supplementation; the only Se present was that of feed ingredients (Table 1). In treatments T2, T3 and T4, the chickens were fed the same basal diet supplemented with additional Se from a yeast source, Sel-Plex ${ }^{\circledR}$ (Alltech Inc, Nicholasville, KY, USA) to provide $0.15,0.3$ and $3 \mathrm{mg} \mathrm{kg}^{-1}$ Se respectively. Recent findings regarding chemical or enzymatic yeast protein hydrolysis revealed that selenomethionine accounts for $90 \%$ of total Se, while selenocystine, $\gamma$-glutamylselenocysteine, selenocystathione, methylselenocysteine and other compounds represent the rest of the total Se (Schrauzer 2006).

The duration of the study was 6 weeks with housing and care of chickens to conform the guidelines of the Faculty of Animal Science and Aquaculture of the Agricultural University of Athens. The chickens were raised, according to Cobb's management manual, in a house where light and ventilation were controlled. The chickens were fed a starter diet to the $2^{\text {nd }}$ wk of their life, a grower diet to the $4^{\text {th }}$ wk and a finisher diet thereafter. Feed and water were provided ad libitum. Each growing phase diet (starter, grower and finisher) contained the same level of added Se which was the appropriate for each experimental treatment (Table 1). The lighting program was 23 hours of light and one hour of dark. Stocking density was according to EU legislation. At weekly intervals, chickens were weighted and the body weight was recorded. Furthermore, feed intake was measured weekly and feed to gain ratio was calculated. At the end of the $4^{\text {th }}$ and $6^{\text {th }}$ week, two chickens per pen were sacrificed by neck dislocation and liver, breast muscle and whole blood samples were collected for determination of trace elements concentration. 


\section{Trace element determination}

The trace element concentrations were determined using inductively coupled plasma mass spectrometry, ICP-MS (Perkin Elmer, Elan 9000, PerkinElmer Life and Analytical Sciences Inc, Waltham, MA, USA). The instrumental parameters of the equipment used were: Nebuliser flow $0.775 \mathrm{~L} / \mathrm{min}$, Vacuum pressure $1.5 \times 10^{-5}$ torr, Lens Voltage $950 \mathrm{~W}$, Analogue Stage Voltage -1900 V, Pulse Stage Voltage 950 V, Sweeps/reading 20, Readings/replicate 1, Number of replicates 3, Time per sample 83 s. Feed samples were collected before feeding and milled before analysis through a $1 \mathrm{~mm}$ sieve (Cyclotec, 1093 sample mill, Tecator, Höganäs, Sweden). Initially, a complete digestion of the samples was performed with a microwave digestion system (CEM, Mars X-Press, NC, USA). Samples (0.5 g) of wet tissue or feed were soaked in $10 \mathrm{ml}$ concentrated $\mathrm{HNO}_{3}(65 \% \mathrm{w} / \mathrm{v}$, Suprapur, Merck, Darmstadt, Germany). The samples were heated in the microwave accelerated digestion system according to the following program: the power was ramped during $20 \mathrm{~min}$ from $100 \mathrm{~W}$ to $1200 \mathrm{~W}$ and held for $15 \mathrm{~min}$. The temperature reached a maximum of $200^{\circ} \mathrm{C}$ and followed by a cool down cycle for $15 \mathrm{~min}$. Losses of volatile element compounds do not occur as the tubes are sealed during heating. The samples were then filtered with disposable syringe filters (Chromafil, Macherey-Nagel, Duren, Germany) and diluted 50 times with reversed osmosis water (MilliQ Water Purification Systems, Billerica, MA, USA) before injection in the ICP-MS instrument. Standard solutions used for calibration curves were prepared from high purity standards (Multielenment standard solution, Fluka Analytical, Sigma-Aldrich, St Louis, USA). The analytical procedure was validated using a Se recovery procedure (Georgiou and Koupparis 1990) and a standard reference material (NIST-RM 8414 -bovine muscle powderLGC Standards Promochem, Wesel, Germany). The Se recovery procedure was as follows: 4 samples from the same liver tissue $(1 \mathrm{~g}$ each) were spiked with 250,500 and $750 \mu \mathrm{l}$ of $\mathrm{Se}$ standard solution of $4 \mathrm{mg} \mathrm{kg}^{-1}$, respectively. The spiked samples were analyzed after the aforementioned analytical procedure. The recoveries of the procedure used to validate ICPMS were in the range of 92.1-105.6\% indicating the accuracy of the method. Regarding the NIST-RM, certified and determined trace element concentrations are presented in Table 2.

\section{Statistical analysis}

The statistical analysis was performed using SPSS for Windows (Chicago, IL, USA). The data were analyzed using a multivariate linear model where $\mathrm{Se}, \mathrm{Cd}, \mathrm{Zn}, \mathrm{Cu}$ and $\mathrm{Fe}$ concentration represented the response variables while treatment, age and tissue were the fixed factors. We tested the hypothesis that the trace element variations are correlated using 
Bartlett's test of sphericity and by calculating the pairwise Pearson correlations. Both methods indicated that the concentrations are indeed correlated, which also reflects biological plausibility. Hence, a multivariate analysis appeared to be necessary. The response variable (Y) was approximately normally distributed as verified by employing both histograms and normality tests. Thus using a multivariate linear model seemed like a reasonable approach. The model was:

$$
Y=\text { intercept }+ \text { age }+ \text { tissue }+ \text { treatment }+(\text { age } X \text { tissue })+(\text { age } X \text { treatment })+
$$
(tissue $X$ treatment $)+($ age $X$ tissue $X$ treatment $)$,

where $\mathbf{Y}$ denotes $\mathrm{Se}, \mathrm{Cd}, \mathrm{Zn}, \mathrm{Cu}$ and $\mathrm{Fe}$ concentrations.

A particular aspect of our analysis was the comparison of the element correlations before and after running the model. In this way, potential differences (or lack thereof) may be revealed, which could otherwise be confounded due to ignoring the factor influence. The statements of significance presented in this study were based on $\mathrm{P} \leq 0.05$ unless otherwise stated. In the Tables, the data are presented as the mean \pm SE of each of the main effects in turn, pooled for all other main effects. Furthermore, in the results section all statistically significant interactions are presented. 


\section{Results}

Supplementation of diet with 150,300 and $3000 \mu \mathrm{g} \mathrm{Se} \mathrm{kg}^{-1}$ significantly $(\mathrm{P}<0.001)$ increased the Se concentration (data pooled for age and tissue effects) by a factor of 1.75, 2.1 and 8.6 respectively compared to the Se concentration of broilers fed the Se unsupplemented diet (Table 3). Overall, the concentration of Se in 6-week old broilers was lower compared with its concentration in 4-wk old broilers (data pooled for treatment and tissue effects, Table 3). The significant age $\mathrm{X}$ treatment interaction $(\mathrm{P}<0.001)$ revealed that Se concentration decreased with age for all four treatments. Tissue type significantly affected Se concentration $(\mathrm{P}<0.001$, data pooled for age and treatment to exacerbate tissue effects, Table 3$)$. Tissue Se concentration in descending order was liver $>$ breast muscle $>$ blood and this pattern was noted for all treatments as indicated by the significant treatment $\mathrm{X}$ tissue interactions $(\mathrm{P}<0.001)$. The age $\mathrm{X}$ tissue interaction $(\mathrm{P}<0.001)$ indicated that Se concentration in blood (pooled for all treatments) decreased as the age of broilers increased (489 \pm 12.7 vs. $\left.379 \pm 12.7 \mu \mathrm{g} \mathrm{kg}^{-1}\right)$. The same was evident in breast muscle $\left(825 \pm 14.2\right.$ vs. $\left.756 \pm 12.7 \mu \mathrm{g} \mathrm{kg}^{-1}\right)$. However, Se concentration in liver increased as the age of broilers increased $(1313 \pm 12.7 \mathrm{vs} .1359 \pm 12.7 \mu \mathrm{g}$ $\left.\mathrm{kg}^{-1}\right)$. The significant treatment $\mathrm{X}$ age $\mathrm{X}$ tissue interactions $(\mathrm{P}<0.001)$ indicated that, although overall increasing age reduced Se concentration, some treatments for some tissues responded different with increasing age. In detail, for broilers fed diet T2, liver Se concentration did not differ as age progressed $\left(784 \pm 25.5\right.$ vs. $\left.787 \pm 25.5 \mu \mathrm{g} \mathrm{kg}^{-1}\right)$. The same was true for liver Se concentration of broilers fed the T3 diet $\left(869 \pm 25.5\right.$ vs. $\left.887 \pm 25.5 \mu \mathrm{g} \mathrm{kg}^{-1}\right)$. However, liver Se concentration of broilers fed T4 increased with age $\left(3090 \pm 25.5\right.$ vs. $\left.3271 \pm 25.5 \mu \mathrm{g} \mathrm{kg}^{-1}\right)$. Finally, liver Se concentration of broilers fed T1 reduced with age $(115 \pm 25.5$ vs. $88 \pm 25.5 \mu \mathrm{g}$ $\left.\mathrm{kg}^{-1}\right)$.

Selenium supplementation significantly $(\mathrm{P}<0.001)$ affected the concentration of $\mathrm{Cd}$ in the examined tissues (Table 3). In detail, Cd concentration in broiler tissues (pooled data) of treatments $\mathrm{T} 2, \mathrm{~T} 3, \mathrm{~T} 4$ was reduced by $41 \%, 37 \%$ and $13 \%$ respectively compared to the concentration of treatment T1. Cadmium concentration in blood was 19.8 times greater $(\mathrm{P}<0.001)$ than that in breast muscle while that in liver was 4.9 times greater than that in breast muscle. The present study revealed significant interactions between treatment and tissue regarding $\mathrm{Cd}$ accumulation. In detail, $\mathrm{Cd}$ concentration in blood of broilers fed diets $\mathrm{T} 2$ $\left(21.3 \pm 0.86 \mu \mathrm{g} \mathrm{kg}^{-1}\right)$ and $\mathrm{T} 3\left(23.8 \pm 0.86 \mu \mathrm{g} \mathrm{kg}^{-1}\right)$ was lower than that of broilers fed Se unsupplemented diets $\left(37 \pm 0.86 \mu \mathrm{g} \mathrm{kg}^{-1}\right)$. Cadmium concentration was greater in 6-wk old broilers compared with its concentration in 4-wk old broilers. Furthermore, the age of broilers affected the $\mathrm{Cd}$ concentration in the tissues as revealed by the age $\mathrm{X}$ tissue interactions 
$(\mathrm{P}=0.001)$. In detail, 6-wk old broilers had higher $\mathrm{Cd}$ concentration in blood compared to 4wk old broilers $\left(38 \pm 0.6\right.$ vs. $\left.21 \pm 0.6 \mu \mathrm{g} \mathrm{kg}^{-1}\right)$. The treatment $\mathrm{X}$ age interaction $(\mathrm{P}<0.001)$ noted in the present study indicated that the increment of $\mathrm{Cd}$ concentration with age differed between treatments. In detail, Cd concentration in tissues of 4-wk vs. 6-wk old broilers fed diets T1, T2, T3 and T4 was $9.7 \pm 0.71$ vs. $23.5 \pm 0.71,9.4 \pm 0.71$ vs. $10.2 \pm 0.71,9.2 \pm 0.71$ vs. $11.6 \pm 0.71$ and $8.9 \pm 0.82$ vs. $20.1 \pm 0.71 \mu \mathrm{g} \mathrm{kg}^{-1}$ respectively. Furthermore, there was a significant $(\mathrm{P}=0.011)$ treatment $\mathrm{X}$ age $\mathrm{X}$ tissue interaction regarding $\mathrm{Cd}$ accumulation. In detail, Cd concentration in the liver of broilers fed diets without added Se increased as the age progressed (5.7 \pm 1.23 vs. $16.4 \pm 1.23 \mu \mathrm{g} \mathrm{kg}^{-1}$ for 4 -wk vs. 6 -wk old broilers respectively).

Iron concentration tended $(\mathrm{P}=0.078)$ to be increased in the tissues of broilers fed $\mathrm{Se}$ supplemented diets (Table 3 ). Tissue type significantly affected Fe concentration $(\mathrm{P}<0.001)$. In particular, blood was the tissue with the highest concentration of Fe. Iron concentration in blood was $391203 \pm 8442 \mu \mathrm{g} \mathrm{kg}^{-1}$ followed by the concentration in liver $\left(199317 \pm 8442 \mu \mathrm{g} \mathrm{kg}^{-}\right.$ $\left.{ }^{1}\right)$ and breast muscle $\left(5985 \pm 8455 \mu \mathrm{g} \mathrm{kg}^{-1}\right)$. Overall, Fe concentration in broilers' tissues did not differ with age, however, the noted age $\mathrm{X}$ tissue interaction $(\mathrm{P}<0.001)$ revealed that blood Fe concentration decreased as the age increased (421838 \pm 11940 vs. $\left.360568 \pm 11940 \mu \mathrm{g} \mathrm{kg}^{-1}\right)$. Furthermore, the treatment $\mathrm{X}$ tissue interactions $(\mathrm{P}<0.05)$ showed that broilers fed the $\mathrm{T} 2$ (425865 $\left.\pm 16885 \mu \mathrm{g} \mathrm{kg}^{-1}\right)$ and T3 (425702 $\left.\pm 16885 \mu \mathrm{g} \mathrm{kg}^{-1}\right)$ diet had greater concentration of Fe in the blood than broilers fed the T1 $\left(360502 \pm 16885 \mu \mathrm{g} \mathrm{kg}^{-1}\right)$ or T4 $\left(352742 \pm 16885 \mu \mathrm{g} \mathrm{kg}^{-1}\right)$ diets.

Zinc concentration in tissues was not affected by Se addition to broiler diets (Table 3). Zinc concentration was 6.6-fold greater in the liver and 1.4-fold greater in the breast muscle than its concentration in the blood. In detail, $\mathrm{Zn}$ concentration in 6-wk old broilers was lower compared with its concentration in 4-wk old broilers. $(\mathrm{P}=0.034)$. Furthermore, the age $\mathrm{X}$ tissue interactions $(\mathrm{P}=0.01)$ indicated that 6-wk old broilers had lower $\mathrm{Zn}$ concentration in blood compared to 4 -wk old broilers $\left(4204 \pm 346\right.$ vs. $\left.3571 \pm 346 \mu \mathrm{g} \mathrm{kg}^{-1}\right)$. The treatment $\mathrm{X}$ age $\mathrm{X}$ tissue interactions $(\mathrm{P}<0.05)$ indicated that as the age of broilers progressed, the $\mathrm{Zn}$ concentration in the blood and liver of broilers fed Se unsupplemented diets decreased (4628 \pm 691 vs. $3099 \pm 691 \mu \mathrm{g} \mathrm{kg}^{-1}$ for blood; $4917 \pm 691$ vs. $4510 \pm 691 \mu \mathrm{g} \mathrm{kg}^{-1}$ for liver).

Copper concentration was not affected by Se addition (Table 3). Liver contained higher $(\mathrm{P}<0.001)$ concentration of $\mathrm{Cu}$ compared to that of blood and breast muscle. There was a tendency $(\mathrm{P}=0.064)$ for 6 -wk old broilers to contain more $\mathrm{Cu}$ that the 4-wk old ones. Although Se supplementation did not affect $\mathrm{Cu}$ accumulation, the treatment $\mathrm{X}$ age $\mathrm{X}$ tissue 
interaction $(\mathrm{P}=0.005)$ showed that $\mathrm{Cu}$ concentration in the liver of broilers fed Se unsupplemented diets decreased along with age (4092 \pm 123 vs. $3170 \pm 123 \mu \mathrm{g} \mathrm{kg}^{-1}$ ).

The correlations between the trace elements before and after the application of the model are presented in Table 4. After the application of the statistical model, the discernible points by inspecting the results were that $\mathrm{Se}$ and $\mathrm{Cu}$ were correlated with all examined trace elements; $\mathrm{Zn}$ was correlated with all examined trace elements except for $\mathrm{Fe}$, and $\mathrm{Cd}$ correlated with all examined trace elements except for Fe. In addition, the value and significance of some pairwise correlations changed by incorporating the factors' influence (Table 4).

Specifically, Se was negatively correlated with $\mathrm{Cd}$ and this relationship became stronger after model application. Similarly, Se correlation with Zn was and remained strongly positive. Likewise, Se correlated positively with $\mathrm{Cu}$ and remained so post-model. In contrast, $\mathrm{Se}$ and Fe appeared uncorrelated in the descriptive statistics, while in fact they were found to correlate positively when the examined factors were taken into account (Table 4). Hence, this association was masked by ignoring the considered factors.

Cadmium was negatively correlated with $\mathrm{Zn}$ and this relationship remained so, albeit weaker after the model application. Furthermore, $\mathrm{Cd}$ and $\mathrm{Cu}$ were negatively correlated and continued to be so post-model. The application of the model revealed that the seemingly strong correlation between $\mathrm{Cd}$ and $\mathrm{Fe}$ was spurious as the two elements were in fact uncorrelated (Table 4).

Zinc and $\mathrm{Cu}$ were strongly positively correlated and their association remained positive although not as profound. Zinc and Fe remained uncorrelated throughout the analysis. Finally, $\mathrm{Cu}$ and $\mathrm{Fe}$ seemed initially uncorrelated, but taking the factors into account exposed a weak negative correlation (Table 4).

\section{Discussion}

This study revealed that supplementation of broilers' diet with Se, not only increased Se concentration but also reduced $\mathrm{Cd}$ concentration in the tissues. Cadmium is absorbed from the gastrointestinal tract and the lung and is mainly accumulated in liver and kidney where it is bound to metallothionein (MT), a low molecular weight cysteine-rich, intracellular protein with high affinity for both essential and non-essential metals (Klaassen et al. 1999). When Cd concentration exceeds the binding capacity of MT, the non-bound Cd causes toxicity possibly due to free radical induction and lipid peroxidation (Sarkar et al. 1997). The administration of Se lowers the toxicity of Cd by shifting the distribution of tissue Cd from MT towards highmolecular-mass proteins (Underwood and Suttle 1999; Wangher 2001). The reduction of Cd 
concentration noted in the present study may be attributed to the formation of $\mathrm{Se}-\mathrm{Cd}$ complexes. Indeed, addition of Se compounds has been proven an efficient therapy against metal toxicity in mammals (Glynn et al. 1993), vegetables (Shanker et al. 1996) and fishes (Paulsson and Lundberg 1989). Although only Se-yeast was examined in this study, inorganic Se has been shown to be effective in reducing the harmful effects of $\mathrm{Cd}$. It has been shown that treatment of rats with Se prior to $\mathrm{Cd}$ administration prevented the effects of $\mathrm{Cd}$, because it bound $\mathrm{Cd}$ to low molecular weight, stable, and biologically inactive $\mathrm{Cd}$ selenide complexes (Ohta et al. 1995). According to available data, it seems that the ability of Se to reduce $\mathrm{Cd}$ accumulation in organs depends on Se/Cd ratio (Sasakura and Suzuki, 1998), their chemical form and the solubility of the formed compounds (Feroci et al., 2005). Schrauzer (2009) reported that the sequestration of toxic elements by Se represents an efficient detoxification mechanism, but also results in the physiological inactivation and loss of Se. In our study, as the age of broilers progressed, Se concentration in tissues decreased, possibly due to involvement of Se in detoxification mechanisms. Decrease of tissue Se content support the idea of Se-Cd complex formation but its excretion or deposition remains unclear. If Se derivatives are supplemented as a remedy for heavy metal toxicity, they should form insoluble compounds to be excreted. Indeed, early findings by Stowe (1976) have shown that Se pretreatment increases the rate of biliary excretion of $\mathrm{Cd}$.

In the present study statistically significant positive correlations between $\mathrm{Se}-\mathrm{Cu}$ and $\mathrm{Se}-\mathrm{Zn}$ were noted. Indeed, broilers fed Se unsupplemented diets exhibited reduced blood and liver $\mathrm{Zn}$ levels as well as reduced liver $\mathrm{Cu}$ levels along with age. Similar results were reported in several other studies where Se was positively correlated to $\mathrm{Cu}$ and $\mathrm{Zn}$. In detail, it was found that $\mathrm{Cu}$ was positively associated with Se in the liver (Lopez-Alonso et al. 2004) and in the kidney (Blanco-Penedo et al. 2006) of cattle raised in Spain. It is possible that the Se - Cd positive correlation may be related to the function of Se as a regulator of MT synthesis, which may in turn hinder biliary excretion of $\mathrm{Cu}$, leading to its accumulation. Earlier studies in ruminants have also demonstrated that after injection of $\mathrm{Se}, \mathrm{Cu}$ concentration in the liver increased in animals receiving both normal (Hussein et al. 1985) or $\mathrm{Cu}$ deficient diets (Thomson and Lawson 1970). However, Kotyzova et al. (2009) reported that in long term Se deficiency of rats an increase of liver $\mathrm{Cu}$ concentration was noted. The positive correlation between $\mathrm{Se}$ and $\mathrm{Zn}$ reported in the present study is in line with reports by Bou et al. (2005) who noted that $\mathrm{Zn}$ supplementation (from $0 \mathrm{mg} \mathrm{kg}^{-1}$ to $600 \mathrm{mg} \mathrm{kg}^{-1}$ ) led to a significant increase in Se content (115 to $213 \mu \mathrm{g} \mathrm{kg}^{-1}$ ) in chicken meat. In the same study, in line with our results, chicken muscle $\mathrm{Zn}$ content decreased with age. This positive $\mathrm{Se}-\mathrm{Zn}$ correlation could 
be attributed to MT, the synthesis of which is induced by Zn and other cations (Nordberg 1998, Nordberg 2009).

In the present study close negative correlations between $\mathrm{Cd}-\mathrm{Zn}$ and $\mathrm{Cd}-\mathrm{Cu}$ were noted. These results are in line with previous studies by Elsenhans et al. (1987) where a decrease of rat hepatic $\mathrm{Cu}$ concentration was observed after a 2-week administration of $\mathrm{Cd}$. Similarly, in the plasma of healthy humans, a negative association between $\mathrm{Cd}$ and $\mathrm{Cu}$ was reported (Pasha et al. 2008). Cadmium shares physiological properties, such as MT-induction, with other elements notably $\mathrm{Cu}$ and $\mathrm{Zn}$ having similar electron configurations in the outer valence shell of the atom. These elements are thus often mutually antagonistic with exposure to $\mathrm{Cd}$ lowering $\mathrm{Cu}$ status and exposure to $\mathrm{Zn}$ lowering $\mathrm{Cd}$ status (Underwood and Suttle 1999). Although it was initially thought that the only function of MTs was to provide a defense against toxic cations (especially $\mathrm{Cd}$ ), it is now known that these proteins have a function in regulating normal $\mathrm{Cu}$ and $\mathrm{Zn}$ metabolism and in protecting cells against damage induced by alkylating agents, oxygen radicals, and ionizing radiation (Lopez-Alonzo et al. 2002). Metallothioneins can also serve as store for $\mathrm{Zn}$ and $\mathrm{Cd}$, and be involved in metal transfer (Phillips et al. 2005; Sharma et al. 2005). The mechanisms by which Cd affects Zn metabolism are not yet well understood but the strong association of $\mathrm{Cd}$ and $\mathrm{Zn}$ in the examined tissues most likely is related to the fact that the handling of $\mathrm{Cd}^{2+}$ and $\mathrm{Zn}^{2+}$ in the tissues intersect at several points. In our study, Cd concentration was greater in 6-wk old broilers compared with its concentration in 4-wk old broilers. The observed $\mathrm{Cd}$ accumulation with time is in line with observations by Nriagu et al. (2008) who reported that Cd contents of older cows were much higher than those of younger animals. In other experimental models (i.e. human or cattle) a positive association between $\mathrm{Cd}$ and $\mathrm{Zn}$ was noted. In detail, in plasma of healthy humans (Pasha et al. 2008) and in the kidney of cattle (Lopez Alonso et al. 2002), a strong positive correlation was observed between $\mathrm{Cd}$ and $\mathrm{Zn}$, indicating that the organism and possibly other factors like the mineral status may affect the association of $\mathrm{Zn}$ and $\mathrm{Cd}$.

Zinc was positively correlated with $\mathrm{Cu}$ in the present study. This result is in line with findings by Nriagu et al. (2008) who reported a positive association of $\mathrm{Cu}$ and $\mathrm{Zn}$ in the liver of free range cattle. Similarly, Blanco-Penedo et al. (2006) reported positive association between $\mathrm{Zn}$ and $\mathrm{Cu}$ in the kidney of cattle raised in Spain. However, there are reports that indicate that a negative correlation between $\mathrm{Cu}$ and $\mathrm{Zn}$ may exist. In detail, when dietary $\mathrm{Zn}$ levels are very high, tissue $\mathrm{Cu}$ concentrations are very low and animals show clinical signs of $\mathrm{Cu}$ deficiency or that low levels of $\mathrm{Zn}$ in the diet lead to $\mathrm{Cu}$ accumulation and $\mathrm{Cu}$ toxicity in ruminants (Mills and Dalgarno 1972), pigs (Poulsen 1998) and laboratory animals (Blalock et 
al. 1988; Hall et al. 1979). Both $\mathrm{Cu}$ and $\mathrm{Zn}$ are integral parts of CuZn-SOD and both these elements together with Se cooperate in the cytosolic antioxidant defense. Copper in excess of cellular needs, mediates free radical production and direct oxidation of lipids, proteins and DNA (Parge et al. 1992). Thus, it seems that a delicate balance between necessity and toxicity for $\mathrm{Cu}$ and $\mathrm{Zn}$ exists which is achieved both at the cellular level and at the tissue and organ levels (Valko et al. 2005).

The present study revealed that in broilers, $\mathrm{Fe}$ was negatively correlated with $\mathrm{Cu}$, positively correlated with Se and uncorrelated with $\mathrm{Cd}$ or $\mathrm{Zn}$. Several studies have confirmed that $\mathrm{Fe}$ and $\mathrm{Cu}$ are associated (Gambling et al. 2008; Pasha et al. 2008). Copper -Fe interactions may occur either at the level of intestinal absorption (Gambling et al. 2008) or during transportation by the DMT1 (divalent metal transporter 1) (Garrick et al. 2003). Iron is involved in the antioxidant defense system of the organism by the action of catalase which is a tetrameric heme-containing enzyme, located primarily in the peroxisomes (Zoidis et al. 2010). Catalase detoxifies $\mathrm{H}_{2} \mathrm{O}_{2}$ by catalyzing its breakdown to water and divalent oxygen. However, ferrous iron is able to trigger oxidations by reducing, as well as by decomposing, previously formed $\mathrm{H}_{2} \mathrm{O}_{2}$ (Fraga and Oteiza 2002). The finding that $\mathrm{Fe}$ is correlated with $\mathrm{Se}$, is in line with previous reports (Uluozlu et al. 2009) and may indicate that occasionally there is a necessity for antioxidant protection against Fe toxicity.

In conclusion, trace elements may interact at the levels of absorption, distribution and retention. Deficiency or supplementation of one of them may alter their balance and trigger antagonistic or synergistic effects. The alteration of trace element balance may concomitantly affect the antioxidant defense system since several trace elements, like $\mathrm{Se}, \mathrm{Cu}, \mathrm{Fe}$ and $\mathrm{Zn}$, are integral part of various antioxidant enzymes. The present study revealed that Se supplementation, age of broiler and type of examined tissue affect the concentration of trace elements. The level of supplemented Se is important since low or excessive quantities may alter the balance and the correlation to the other elements. Although, significant trace element correlations were reported in this study, they do not necessarily indicate that the level of essential elements, like Se, can determine the amount of toxic metal accumulation in broiler tissues or that toxic metal accumulation in tissues can affect essential element homeostasis. Future studies may further elucidate trace element interactions.

\section{Acknowledgements}


A.C Pappas is grateful to Greek State Scholarship Foundation (IKY) for postdoctoral funding. We are grateful to NUEVO S.A. (N Artaki, Euboia, Greece) for providing Sel-Plex ${ }^{\circledR}$, to E. Komaitis for excellent technical assistance and to A. Kominakis for useful discussions. 


\section{References}

Bires J, Dianovsky J, Bartko P, Jusanova Z. 1995. Effects on enzymes and the genetic apparatus of sheep after administration of samples from industrial emissions. Biometals 8:5358.

Blalock TL, Dunn MA, Cousins RJ. 1988. Metallothionein gene expression in rats: tissuespecific regulation by dietary copper and zinc. J Nutr 118:222-228.

Blanco-Penedo I, Cruz JM, López-Alonso M, Miranda M, Castillo C, Hernández J, Benedito JL. 2006. Influence of copper status on the accumulation of toxic and essential metals in cattle. Environ Int 32:901-906.

Bou R, Guardiola F, Barroeta AC, Codony R. 2005. Effect of dietary fat sources and zinc and selenium supplements on the composition and consumer acceptability of chicken meat. Poult Sci 84:1129-1140.

Elsenhans B, Schmolke G, Kolb K, Stokes J, Forth W. 1987. Metal-metal interactions among dietary toxic and essential trace metals in the rat. Ecotoxicol Environ Saf 14:275-287.

Feroci G, Badiello R, Fini A. 2005. Interactions between different selenium compounds and zinc, cadmium and mercury. J Trace Elem Med Biol 18:227-34.

Fraga CG, Oteiza PI. 2002. Iron toxicity and antioxidant nutrients. Toxicology 180:23-32.

Gambling L, Andersen HS, McArdle HJ. 2008. Iron and copper, and their interactions during development. Biochem Soc Trans 36:1258-1261.

Garrick MD, Núñez MT, Olivares M, Harris ED. 2003. Parallels and contrasts between iron and copper metabolism. Biometals 16:1-8.

Georgiou CA, Koupparis MA. 1990. Automated flow injection spectrophotometric determination of para- and meta-substituted phenols of pharmaceutical interest based on their oxidative condensation with 1-nitroso-2-naphthol. Analyst 115:309-313.

Glynn AW, Ilback NG, Brabencova D, Carlsson L, Enqvist EC, Netzel E, Oskarsson A. 1993. Influence of sodium selenite on ${ }^{203} \mathrm{Hg}$ absorption, distribution and elimination in male mice exposed to methyl ${ }^{203} \mathrm{Hg}$. Biol Trace Elem Res 39:91-107. 
Goyer RA. 1997. Toxic and essential metal interactions. Annu Rev Nutr 17:37-50.

Hall AC, Young BW, Bremner I. 1979. Intestinal metallothionein and the mutual antagonism between copper and zinc in the rat. J Inorg Biochem 11:57-66.

Hussein KSM, Jones BE, Frank A. 1985. Selenium copper interaction in goats. Zbl Vet Med A 32:321-330.

Jemai H, Messaoudi I, Chaouch A, Kerkeni A. 2007. Protective effect of zinc supplementation on blood antioxidant defense system in rats exposed to cadmium. J Trace Elem Med Biol 21:269-273.

Jihen EH, Messaoudi I, Fatima H, Kerkeni A. 2008. Protective effects of selenium (Se) and zinc $(\mathrm{Zn})$ on cadmium $(\mathrm{Cd})$ toxicity in the liver and kidney of the rat: Histology and $\mathrm{Cd}$ accumulation. Food Chem Toxicol 46:3522-3527.

Klaassen CD, Liu J, Choudhuri S. 1999. Metallothionein: an intracellular protein to protect against cadmium toxicity. Food Chem Toxicol 39:267-294.

Klotz LO, Kröncke KD, Buchczyk DP, Sies H. 2003. Role of Copper, Zinc, Selenium and Tellurium in the Cellular Defense against Oxidative and Nitrosative Stress. J Nutr 133:14481451.

Kotyzová D, Černá P, Lešetický L, Eybl V. 2009. Trace Elements Status in SeleniumDeficient Rats-Interaction with Cadmium. Biol Trace Elem Res doi: 10.1007/s12011-009$8541-4$

Lopez-Alonso M, Benedito JL, Miranda M, Castillo C, Hernandez J, Shore RF. 2002. Cattle as biomonitors of soil arsenic, copper and zinc concentrations in Galicia (NW Spain). Arch Environ Contam Toxicol 43:103-108.

Lopez-Alonso M, Miranda M, Castillo C, Hernandez J, Garcia-Vaquero M, Benedito JL. 2007. Toxic and essential metals in liver, kidney and muscle of pigs at slaughter in Galicia, north-west Spain. Food Addit Contam 24:943-954.

Lopez-Alonso ML, Montaña FP, Miranda M, Castillo C, Hernandez J, Benedito JL. 2004. Interactions between toxic ( $\mathrm{As}, \mathrm{Cd}, \mathrm{Hg}$ and $\mathrm{Pb}$ ) and nutritional essential $(\mathrm{Ca}, \mathrm{Co}, \mathrm{Cr}, \mathrm{Cu}, \mathrm{Fe}$, Mn, Mo, Ni, Se, Zn) elements in the tissues of cattle from NW Spain. Biometals 17:389-397. 
Mills CF, Dalgarno AC. 1972. Copper and zinc status of ewes and lambs receiving increased dietary concentrations of cadmium. Nature 239:171-173.

National Research Council. 1994. Nutrient Requirements of Poultry. 9th rev. ed. National Academy Press, Washington, DC.

Nordberg GF. 2009. Historical perspectives on cadmium toxicology. Toxicol Appl Pharmacol 238:192-200.

Nordberg M. 1998. Metallothioneins: Historical review and state of knowledge. Talanta 46:243-254.

Nriagu J, Boughanen M, Linder A, Howe A, Grant C, Rattray R, Vutchkov M, Lalor G. 2009. Levels of $\mathrm{As}, \mathrm{Cd}, \mathrm{Pb}, \mathrm{Cu}, \mathrm{Se}$ and $\mathrm{Zn}$ in bovine kidneys and livers in Jamaica. Ecotoxicol Environ Saf 72:564-571.

Ognjanovic BI, Markovic SD, Dordevic NZ, Trbojevic IS, Stajna AS, Saici ZS. 2010. Cadmium-induced lipid peroxidation and changes in antioxidant defense system in the rat testes: Protective role of coenzyme Q10 and Vitamin E. Reprod Toxicol 29:191-197.

Ohta H, Seki Y, Yoshikawa H. 1995. Interactive effects of selenium on chronic cadmium toxicity in rats. ACES Bull 8:97-104.

Pappas AC, Zoidis E, Fegeros K, Surai PF, Zervas G. 2010a. Cadmium toxicity and the antioxidant system. Nova Science Publishers, New York, (In press).

Pappas AC, Zoidis E, Fegeros K, Surai PF, Zervas G. 2010b. Relation of cadmium to other elements and the antioxidant system. In: Parvau PG Cadmium in the Environment, Nova Science Publishers, New York, pp 263-295.

Pappas AC, Zoidis E, Surai PF, Zervas G. 2008. Selenoproteins and maternal nutrition Comp Bioch Physiol B 151:361-372.

Parge H E, Hallewell R A, Tainer J A. 1992. Atomic structures of wild-type and thermostable mutant recombinant human $\mathrm{Cu}, \mathrm{Zn}$ superoxide dismutase. Proc Natl Acad Sci U.S.A. 89:6109-6113. 
Pasha Q, Malik SA, Shah MH. 2008. Statistical analysis of trace metals in the plasma of cancer patients versus controls. J Hazard Mater 153:1215-1221.

Paulsson K, Lundbergh K. 1989. The selenium method for treatment of lakes for elevated levels of mercury in fish. Sci Total Environ 87-88:495-507.

Payne RL, Lavergne TK, Southern LL. 2005. Effect of inorganic versus organic selenium on hen production and egg selenium concentration. Poult Sci 84:232-237.

Petersson-Grawe K, Thierfelder T, Jorhem L, Oskarsson A. 1997. Cadmium levels in kidneys from Swedish pigs in relation to environmental factors - temporal and spatial trends. Sci Tot Environ 208:111-122.

Phillips CJC, Chiy PC, Zachou E. 2005. Effects of cadmium in herbage on the apparent absorption of elements by sheep in comparison to inorganic cadmium added to their diets. Environ Res 99:224-234.

Poulsen HD. 1998. Zinc and copper as feed additives, growth factors or unwanted environmental factors. J Anim Feed Sci 7:135-142.

Sarkar S, Yadav P, Bhatnager D. 1997. Cadmium-induced lipid peroxidation and the antioxidant system in rat erythrocytes: the role of antioxidants. J Trace Elem Med Biol 11:813.

Sasakura C, Suzuki KT. 1998. Biological interaction between transition metals (Ag, Cd and $\mathrm{Hg}$ ), selenide/sulfide and selenoprotein P. J Inorg Biochem 71:159-62.

Schrauzer G N. 2009. Selenium and selenium-antagonistic elements in nutritional cancer prevention. Crit Rev Biotechnol 29:10-17.

Schrauzer GN. 2006. Selenium yeast: Composition, quality, analysis, and safety. Pure Appl Chem 78:105-109.

Serra-Majem L, Pfrimer K, Doreste-Alonso J, Ribas-Barba L, Sánchez-Villegas A, OrtizAndrellucchi A, Henríquez-Sánchez P. 2009. Dietary assessment methods for intakes of iron, calcium, selenium, zinc and iodine. Br J Nutr 102:38-55. 
Shanker K, Mishra S, Srivastava S, Srivastava R, Dass S, Prakash S, Srivastava MM. 1996. Study of mercury-selenium $(\mathrm{Hg}-\mathrm{Se})$ interactions and their impact on $\mathrm{Hg}$ uptake by the radish (Raphanus sativus) plant. Food Chem Toxicol 34:883-886.

Sharma MC, Joshi C, Pathak NN, Kaur H. 2005. Copper status and enzyme, hormone, vitamin and immune function in heifers. Res Vet Sci 79:113-123.

Southgate D, Johnson I, Fenwick GR. 1989. Conceptual issues concerning the assessment of nutrient bioavailability. In Southgate D, Johnson I, Fenwick GR Nutrient Availability: Chemical and Biological Aspects. Cambridge University Press, pp 85-102.

Strachan S. 2010. Trace elements. Curr Anaesth Crit Care 21:44-48.

Stowe HD. 1976. Biliary excretion of cadmium by rats: effects of zinc, cadmium, and selenium pretreatments. J Toxicol Environ Health 2:45-53.

Thomson GG, Lawson BM. 1970. Copper and selenium interaction in sheep. N Z Vet J 18:79-82.

Tuzen M, Soylak M. 2007. Determination of trace metals in canned fish marketed in Turkey. Food Chem 101:1378-1382.

Uluozlu OD, Tuzen M, Mendil D, Soylak M. 2009. Assessment of trace element contents of chicken products from turkey. J Hazard Mater 163:982-987.

Underwood EJ, Suttle NF. 1999. The mineral nutrition of livestock, 3rd ed. CAB International Wallingford.

Valko M, Morris H, Cronin MTD. 2005. Metals, Toxicity and Oxidative Stress. Curr Med Chem 12:1161-1208.

Wangher PD. 2001. Selenium and the brain: A review. Nutr Neurosci 4:81-97.

Webb M. 1979. The chemistry, biochemistry and biology of cadmium. Topics in environmental health. Elsevier, Amsterdam.

WHO, 1996. Trace elements in human nutrition and health, WHO, Geneva. 
Zoidis E, Pappas AC, Georgiou CA, Komaitis E, Fegeros K. 2010. Selenium affects the expression of GPx4 and catalase in the liver of chicken. Comp Bioch Physiol B 155:294-300. 
Table 1. Composition $\left(\mathrm{g} \mathrm{kg}^{-1}\right)$ of control and Se-supplemented diets for chickens

\begin{tabular}{|c|c|c|c|}
\hline $\begin{array}{l}\text { Ingredients } \\
(\mathrm{g} / \mathrm{kg})\end{array}$ & $\begin{array}{l}\text { Starter } \\
(0-2 \text { wk })\end{array}$ & $\begin{array}{l}\text { Grower } \\
\text { (2-4 wk) }\end{array}$ & $\begin{array}{l}\text { Finisher } \\
\text { (4-6 wk) }\end{array}$ \\
\hline Maize & 579.4 & 618.5 & 666.5 \\
\hline Soybean meal & 332.8 & 287.2 & 251.5 \\
\hline Soya oil & 42.7 & 52.7 & 43.0 \\
\hline Dicalcium phosphate & 16.2 & 15.3 & 14.2 \\
\hline Limestone & 13.6 & 11.1 & 10.8 \\
\hline Lysine & 2.6 & 3.1 & 2.6 \\
\hline Methionine & 3.7 & 3.8 & 3.4 \\
\hline $\mathrm{NaCl}$ & 5.0 & 4.3 & 4.0 \\
\hline Premix ${ }^{a}$ & 4.0 & 4.0 & 4.0 \\
\hline Treatment & \multicolumn{2}{|c|}{ Se $\operatorname{added}^{\mathrm{b}}\left(\mu \mathrm{g} \mathrm{kg}^{-1}\right)$} & Se determined ${ }^{\mathrm{c}}\left(\mu \mathrm{g} \mathrm{kg}^{-1}\right)$ \\
\hline $\mathrm{T} 1$ & & & $210 \pm 14$ \\
\hline $\mathrm{T} 2$ & & & $443 \pm 19$ \\
\hline $\mathrm{T} 3$ & & & $685 \pm 29$ \\
\hline $\mathrm{T} 4$ & & & $3683 \pm 210$ \\
\hline
\end{tabular}

${ }^{\text {a }}$ Premix supplied per kg of diet: 12000 IU vitamin A (retinyl acetate), 4000 IU vitamin $\mathrm{D}_{3}$ (cholecalciferol), $80 \mathrm{mg}$ vitamin $\mathrm{E}$ (DL- $\alpha$-tocopheryl acetate), $9 \mathrm{mg}$ vitamin $\mathrm{K}_{3}, 3 \mathrm{mg}$ thiamin, $7 \mathrm{mg}$ riboflavin, $6 \mathrm{mg}$ vitamin $\mathrm{B}_{6}, 25 \mu \mathrm{g}$ vitamin $\mathrm{B}_{12}, 50$ $\mathrm{mg}$ nicotinic acid, $15 \mathrm{mg}$ pantothenic acid, $1.5 \mathrm{mg}$ folic acid, $0.15 \mathrm{mg}$ biotin, $400 \mathrm{mg}$ choline, $1.5 \mathrm{mg}$ iodine, $50 \mathrm{mg}$ iron, $130 \mathrm{mg}$ manganese, $20 \mathrm{mg}$ copper, $0.25 \mathrm{mg}$ cobalt, $100 \mathrm{mg}$ zinc. No Se was provided in the vitamin-mineral premix.

${ }^{\mathrm{b}} \mathrm{Se}$ was added in the form of Sel-Plex (Alltech Inc, Nicholasville, KY, USA) and only in the Se-supplemented diets.

${ }^{\mathrm{c}}$ The determined Se content represents pooled data from all three diets (starter, grower and finisher). 
Table 2. Determined and certified trace element concentrations in the reference material (NIST-RM 8414 -bovine muscle powder)

\begin{tabular}{cccc}
\hline Element & Certified value $\left(\boldsymbol{\mu} \mathbf{g ~ g}^{-\mathbf{1}}\right)$ & Detected Value $\left(\boldsymbol{\mu g} \mathbf{g}^{-\mathbf{1}}\right)$ & Recovery $(\boldsymbol{\%})$ \\
\hline $\mathrm{Se}$ & $0.076 \pm 0.010$ & $0.078 \pm 0.011$ & 103 \\
$\mathrm{Cd}$ & $0.013 \pm 0.011$ & $0.016 \pm 0.002$ & 123 \\
$\mathrm{Zn}$ & $142 \pm 14$ & $173 \pm 1$ & 122 \\
$\mathrm{Cu}$ & $2.84 \pm 0.45$ & $3.26 \pm 0.08$ & 115 \\
$\mathrm{Fe}$ & $71.2 \pm 9.2$ & $91.97 \pm 1.03$ & 129 \\
\hline
\end{tabular}


Table 3. The effect of Se supplementation in the diet of broilers on the concentration $\left(\mu \mathrm{g} \mathrm{kg}^{-1}\right)$ of $\mathrm{Se}, \mathrm{Cd}, \mathrm{Zn}, \mathrm{Cu}$ and $\mathrm{Fe}$ in blood, liver and breast tissue at $4^{\text {th }}$ and $6^{\text {th }}$ week of age

\begin{tabular}{|c|c|c|c|c|c|}
\hline \multirow{2}{*}{$\begin{array}{l}\text { Factor } \\
\text { Studied }^{\text {a }}\end{array}$} & \multicolumn{5}{|c|}{ Trace Element } \\
\hline & Se & Cd & $\mathbf{Z n}$ & $\mathbf{C u}$ & $\mathbf{F e}$ \\
\hline \multicolumn{6}{|l|}{ Age (wk) } \\
\hline $4^{\text {th }}$ & $876^{\mathrm{a}} \pm 7.65$ & $9.3^{\mathrm{a}} \pm 0.37$ & $12076^{\mathrm{a}} \pm 208$ & $1451 \pm 37.14$ & $201635 \pm 7175$ \\
\hline $6^{\text {th }}$ & $831^{\mathrm{b}} \pm 7.35$ & $16.4^{\mathrm{b}} \pm 0.36$ & $11454^{\mathrm{b}} \pm 200$ & $1354 \pm 35.68$ & $196034 \pm 6893$ \\
\hline \multicolumn{6}{|l|}{$\begin{array}{l}\text { Se added } \\
\left(\mu \mathrm{gg}^{-1}\right)\end{array}$} \\
\hline 0 (T1) & $252^{\mathrm{a}} \pm 10.40$ & $16.6^{\mathrm{a}} \pm 0.50$ & $11935 \pm 282$ & $1452 \pm 50.46$ & $180568 \pm 9749$ \\
\hline $150(\mathrm{~T} 2)$ & $441^{b} \pm 10.40$ & $9.8^{\mathrm{b}} \pm 0.50$ & $12031 \pm 282$ & $1462 \pm 50.46$ & $216623 \pm 9749$ \\
\hline 300 (T3) & $534^{c} \pm 10.40$ & $10.4^{\mathrm{b}} \pm 0.50$ & $11313 \pm 282$ & $1340 \pm 50.46$ & $202732 \pm 9449$ \\
\hline 3000 (T4) & $2186^{\mathrm{d}} \pm 11.20$ & $14.5^{\mathrm{c}} \pm 0.55$ & $11781 \pm 305$ & $1355 \pm 54.50$ & $195416 \pm 10530$ \\
\hline \multicolumn{6}{|l|}{ Tissue } \\
\hline Blood & $434^{\mathrm{a}} \pm 9.00$ & $29.7^{\mathrm{a}} \pm 0.44$ & $3888^{\mathrm{a}} \pm 244$ & $393^{\mathrm{a}} \pm 43.70$ & $391203^{\mathrm{a}} \pm 8442$ \\
\hline Liver & $1336^{\mathrm{b}} \pm 9.00$ & $7.4^{\mathrm{b}} \pm 0.44$ & $25766^{\mathrm{b}} \pm 244$ & $3481^{\mathrm{b}} \pm 43.70$ & $199317^{\mathrm{b}} \pm 8442$ \\
\hline Breast & $790^{c} \pm 9.55$ & $1.5^{\mathrm{c}} \pm 0.46$ & $5641^{c} \pm 259$ & $332^{\mathrm{a}} \pm 46.35$ & $5985^{\mathrm{c}} \pm 8955$ \\
\hline $\begin{array}{l}\text { Source of } \\
\text { Variation }\end{array}$ & & & P Value & & \\
\hline $\begin{array}{l}\text { Treatment } \\
\text { (Se } \\
\text { addition) }\end{array}$ & $<0.001$ & $<0.001$ & NS & NS & $\begin{array}{c}\mathrm{NS} \\
(\mathrm{P}=0.078)\end{array}$ \\
\hline Age & $<0.001$ & $<0.001$ & 0.034 & $\begin{array}{c}\mathrm{NS} \\
(\mathrm{P}=0.064)\end{array}$ & NS \\
\hline Tissue & $<0.001$ & $<0.001$ & $<0.001$ & $<0.001$ & $<0.001$ \\
\hline $\begin{array}{l}\text { Treatment } \\
\text { X Age }\end{array}$ & $<0.001$ & $<0.001$ & NS & NS & NS \\
\hline $\begin{array}{l}\text { Treatment } \\
\text { X Tissue }\end{array}$ & $<0.001$ & $<0.001$ & NS & NS & $<0.05$ \\
\hline $\begin{array}{l}\text { Age } X \\
\text { Tissue }\end{array}$ & $<0.001$ & $<0.001$ & $<0.01$ & NS & $<0.001$ \\
\hline $\begin{array}{l}\text { Treatment } \\
\text { X Age X } \\
\text { Tissue }\end{array}$ & $<0.001$ & $<0.001$ & $<0.05$ & $<0.01$ & NS \\
\hline
\end{tabular}

${ }^{a}$ The data are presented as means \pm SE $(n=4)$ of the main effect in turn, pooled for all other main effects, based on Multivariate Regression.

Means within a column, within a main effect comparison, with different superscripts are different at $\mathrm{P}<0.05$, unless otherwise stated. 
Table 4. Correlations between the concentration of $\mathrm{Se}, \mathrm{Cd}, \mathrm{Zn}, \mathrm{Cu}, \mathrm{Fe}$ prior to and after the application of the statistical model

\begin{tabular}{ccccc}
\hline $\begin{array}{c}\text { Prior to Model } \\
\text { Application }\end{array}$ & $\mathbf{C d}$ & $\mathbf{Z n}$ & $\mathbf{C u}$ & $\mathbf{F e}$ \\
\hline $\mathbf{S e}$ & $-0.213^{*}$ & $0.378^{* * *}$ & $0.356^{* * * *}$ & -0.112 \\
$\mathbf{C d}$ & & $-0.346^{* * *}$ & $-0.279^{* *}$ & $0.654^{* * *}$ \\
$\mathbf{Z n}$ & & $0.978^{* * *}$ & -0.042 \\
$\mathbf{C u}$ & & & 0.087 \\
\hline After the Model & $\mathbf{C d}$ & $\mathbf{Z n}$ & $\mathbf{C u}$ & $\mathbf{F e}$ \\
Application & $-0.389^{* * *}$ & $0.461^{* * *}$ & $0.312^{* *}$ & $0.229^{*}$ \\
\hline $\mathbf{S e}$ & & $-0.249^{*}$ & $-0.236^{*}$ & -0.189 \\
$\mathbf{C d}$ & & $0.390^{* * *}$ & 0.073 \\
$\mathbf{Z n}$ & & & $-0.267^{*}$ \\
$\mathbf{C u}$ & & & & \\
\hline
\end{tabular}

Level of statistical significance of each of the pairwise correlations, $* \mathrm{P} \leq 0.05 ; * * \mathrm{P} \leq 0.01$; $* * * \mathrm{P} \leq 0.001$. 